Débora Mascella Krieger ${ }^{1}$

Dhttps://orcid org/0000-0001-7795-065

Luiz Carlos Illafont Coronel² Ohttps://orcid.org/0000-0001-8550-1952

Liliane Dias de Lima²

Ohttps://orcid.org/0000-0002-5439-0476

\section{The relevance of Mini Mental State Examination (MMSE) use on demential interdiction exams in judicial proceedings}

\author{
A importância do Miniexame do Estado Mental (MEEM) nos \\ exames de interdição demencial em processos judiciais
}

D0I: $10.1590 / 0047-2085000000259$

\begin{abstract}
Objective: To highlight the important role of Mini Mental State Examination (MMSE) use on judicial interdiction assessments. Methods: On this paper, we present a case in which we have used the Mini mental state examination (MMSE) for screening an initial dementia diagnosis, suggested by clinical and mental state examination. Results: The relevance of using a screening test for demencial states on judicial interdictions assessments, as MMSE, in order to provide more objective findings to the court, has been demonstrated. Also, we review the current evidence for using MMSE on this setting and the importance of its use on demential interdiction exams in judicial proceedings. Conclusions: Judicial evidence is a critical element in decision making. Judicial interdiction assessment is usually performed by expert psychiatrists. As psychiatric diagnosis relies on clinical history and mental state examination, it is composed of subjective elements, varying also according to the examiner's personal technical orientation and impressions. Neuroimaging exams are helpful on a minority of cases, in which specific findings are present. In such cases, clinical screening questionnaires play an important role - providing objective elements of neuropsychic functioning of an individual, thus limiting the subjective realm of the expert forensic report.
\end{abstract}

\section{KEYWORDS}

Forensic psychiatry, judicial assessment, judicial interdiction, dementia, Mini Mental State Examination (MMSE).

\section{RESUMO}

Objetivo: Destacar a importância do uso do Miniexame do Estado Mental (MEEM) nas perícias de interdição judicial por demência. Métodos: Neste artigo, apresentamos um caso no qual aplicamos - MEEM para rastreamento de demência inicial, cujo diagnóstico foi sugerido por meio de história clínica e exame do estado mental. Resultados: Foi demonstrada a importância de usar um teste de rastreamento para demência, no caso o MEEM, nas perícias de interdição por esse diagnóstico, a fim de fornecer elementos mais objetivos ao juízo. Ainda, fornecemos uma revisão das evidências atuais para a aplicação do MEEM nesse contexto, bem como a importância do uso dele nas perícias de interdição por demência. Conclusões: A prova pericial é um elemento crítico para a tomada de decisão judicial. A perícia de interdição judicial por demência é usualmente realizada por especialistas em psiquiatria. Como o diagnóstico psiquiátrico baseia-se na história clínica e no exame do estado mental, é composto de elementos subjetivos, variando de acordo com a técnica e impressão individual do examinador. Exames de neuroimagem são úteis em uma minoria de casos, nos quais achados específicos estão presentes. Assim, questionários clínicos para rastreamento de doenças mostram-se importantes, pois fornecem elementos objetivos do funcionamento neuropsíquico do indivíduo, diminuindo o papel da subjetividade no laudo pericial.

\section{PALAVRAS-CHAVE}

Psiquiatria forense, pericias judiciais, interdição judicial, demência, Miniexame do Estado Mental (MEEM). 


\section{INTRODUCTION}

Judicial evidence is a critical element in decision making. Although the judicial proceeding uses different evidence the expert analysis assumes a prevalent role due to its technical content regarding the matter it refers'. It is usually performed by an expert on the field, having the judge's confidence on the task. Therefore, the clearer the expert analysis report is, the better it will serve the court decision making.

Judicial interdiction assessment is usually performed by expert psychiatrists. The diagnosis in psychiatry relies on clinical history and on judicial mental state examination ${ }^{2,3}$. However, many of these findings will depend on the particular characteristics of the professional administering the exam, and the weight given by such professional to the elements found present on each individual assessment. Accordingly, the resulting conclusions for objectively similar situations may vary considerably.

Neuroradiologic exams are widely used to diagnose dementia based on anatomic/structural findings. Nevertheless, they poorly describe the patient's global mental functioning. In order to list more objective and reproducible elements concerting neurologic functional aspects, clinical screening tests for diseases can be used ${ }^{2,3}$. We have selected the Mini mental state examination (MMSE) ${ }^{4}$ because of its easy accessibility and application, as well as its proven efficiency on the secondary role of identifying demential cases.

Important to observe that Brazilian Act n. 13.146 has altered the interdiction legal framework. This Act (the "Lei Brasileira de Inclusão da Pessoa com Deficiência - Estatuto da Pessoa com Deficiência") aims at promoting, and ensuring the exercise of, the rights conferred upon the mentally ill, with a view to the inclusion of such person in society, in all respects. The terms of this Act deny "interdição total" in Brazil: a mentally ill individual is entitled to maintain minimum rights to the administration of her assets and to exercise other routine actions in her civil capacity, to the full extent allowable, considered her mental condition ${ }^{5}$.

In this paper, we describe one of a serie of cases in which the MMSE was used as a complementary test to dementia screening on demential interdiction exams in judicial proceedings. Also, we review the current evidence for using MMSE on recent literature and on the former specific setting, demonstrating the importance of its use on demential interdiction exams in judicial proceedings.

\section{Medical history and expert mental state examination}

Just as in clinical practice, the interview is the most important of the diagnose activities ${ }^{2,3}$. From its elements, we can colect data regarding clinical and family histories of the evaluated individual, and perform the expert mental state examination ${ }^{2,3}$. From these assessments, it is possible to obtain the main elements for the psychiatric diagnosis and to evaluate the examinee's understanding ability. The latter is the main aspect to be considered on interdiction exams in judicial proceedings.

The interview and expert mental state examination should be registered in a very clear and technical way, respecting the visum et repertum ${ }^{6}$ recommendation for such evaluations. As lined before, these exams vary according to the expert performing them, as they can be heavily influenced by the examiner's particular assessment.

\section{The relevance of complimentary clinical testing in forensic evaluations}

The importance of complementary clinical testing in forensic evaluations may provide enhanced elements to the conclusion reached in judicial proceedings, aiding the judges in the discharge of their duties. In this respect, it seems very important to add objective clinical elements to expert analysis? ${ }^{7}$. With this procedure, it is also possible to avoid some of the most cited criticisms to the expert opinions: the subjective variability and the lack of reproducible methods ${ }^{8}$.

Only in limited circumstances, neuroimaging brain exams provide objective data regarding cerebral anatomic functioning9. In the relatively few incidences when their findings are conclusive, they serve as invaluable support to the expert forensic evaluations and judicial findings. They aid in the determination of the extent of an individual's brain functioning and discernment ${ }^{10}$. The lack of biomarkers that can unequivocally demonstrate the mental disorders stresses the importance of the imaging exams, especially when used in a secondary role in psychiatric evaluation ${ }^{2,3}$. On the other hand, however, complementary imaging exams in psychiatry are costly and controversial ${ }^{11,12}$, also delaying expert and processual conclusions.

The aim is to obtain the most objective evaluations possible on individual's impairment functioning assessment. On this setting, the application of already validated clinical tests to specific diseases screening (chosen by history and mental state examination findings) is important and welcomed in judicial proceedings ${ }^{13}$.

\section{Non-diagnosed dementia prevalence on general population}

The dementia detection rate on general population can be very low, mainly in adult subjects showing declines in memory and changes in brain activity. It is sometimes considered as part of aging ${ }^{14}$. In a recent metanalysis ${ }^{15}$, the mean prevalence of non- diagnosed dementia affected individuals in a certain general population was estimated as $61 \%$ (95\% Cl 55.0\% to 68.0\%). On studies in which MMSE was applied, the under diagnosis of dementia was even lower. 


\section{Mini Mental State Examination (MMSE) for dementia screening}

Folstein's MMSE ${ }^{4}$ is one of the earliest described questionnaires to screen demential states already validated for this purpose. As part of general medical training, physicians usually receive education for its application. It is the most widely used test ${ }^{16}$ to evaluate cognitive function because of its short time duration (around ten minutes), its simplicity to perform, and its absence of specific material requirement. It should be used as a screening instrument, not as a substitute for a more detailed evaluation. Although it assesses several aspects, like space and time orientation, global memories, calculation, capacity to recognize objects, repetition, comprehension, writing and drawing, it does not serve as diagnostic test. On the other hand, it is a proper test for indicating mental functions that need further investigation. It is one of few tests validated and adapted for Brazilian population.

MMSE has shown to have good psychometric properties for dementia screening in primary care setting $\mathrm{s}^{17}$. In secondary care, it can present lower sensibility than in the first one described, but its use is still recommended ${ }^{17,18}$. In a wide Cochrane review ${ }^{18}$, the authors still recommend MMSE use as part of dementia diagnostic evaluation, though it should not be solely used to exclude or to confirm the diagnosis.

In certain circumstances, where the clinical history suggests cognitive or functional loss (such as by reports provided by family members or other closely related individuals), a general screening cognitive test is usually administered. This is the case of MEEM, which may be sufficient to the diagnosis of "dementia." One of the most important aspects in this initial screening is to determine which areas are affected in the individual. Once the area of impairment is identified, the severity of such impairment must be assessed. In this respect, one of the most popular methods is the use of "Clinical Dementia Rating" (CDR), which is beyond the scope of this study.

\section{CASE REPORT}

An 86-year-old, widowed man, high school graduated, house-builder, born in Porto Alegre city, Brazil (the "Examinee"), was interviewed in connection with a demential interdiction exams ordered by a state judge. Three of the Examinee's four sons started the judicial process for interdiction, claiming waste of assets by their father. The Examinee argued against this proposition and contested the legal action.

During the psychiatric interview, he was found aware of the objectives of the evaluation, blaming the legal action to his offspring's greed. The Examinee lived alone, while the only son opposing the legal measures administers a company along with his father. In addition, this child assisted his father personally and professionally whenever necessary.

The Examinee reports having worked as a constructor at a federal state university during seventeen years, having later retired. He founded a construction company as part of his professional activities, from which he was able to amass a substantial number of assets. He reported ownerships of 13 apartments, estimated to be worth about 2 million reais, the Brazilian currency. The Examinee earned additional income from renting some

of these buildings (estimating four thousand reais monthly) and also received certain retirement benefits. He used a hearing aid device, which he claimed to have acquired for twelve thousand reais. As to the Examinee's expenses, he reported bank loans that consumed a substantial part of his monthly income. He referred regularly paying a sum of money to his granddaughter - the daughter of his only son opposing the legal measures. The Examinee claimed to drive his own car, to vote and to hold a license to carry and using a firearm.

Although he exhibits some lapses of memory during his examination, the Examinee denied having health problems of any kind, including neurologic/psychiatric ones. He denied use of licit or illicit drugs of any kind, as well as of any medications. He objected to his interdiction and accused his former lawyer of colluding with his sons in order to get access his assets. The individual wasn't able to explain the reasons for, or the process resulting in, her personal debt, including his personal expenses, such as utility bills, as well as the substantial decrease in his assets occurred in the previous years. This inability is in sharp contrast to his performance of the same tasks in the past, evidencing a substantial loss in his mental capacity.

His eldest son was present during the psychiatric examination, after obtaining due permission from the parties involved. This individual informed that the Examinee was at the time responding to about a hundred judicial proceedings for delinquency in the payment of taxes regarding his buildings. Because of the Examinee's impulsive actions, he has incurred many debts, evidencing his inability to manage his affairs in the same way as performed in the past. As a result, claimed the son, the Examinee compromised a substantial amount of his assets. We asked the Examinee to perform a test for his memory, and he agreed to it.

\section{Expert mental state examination}

Established a direct, active, and productive interaction with the examiner.

General aspects: Good personal hygiene, tall and skinny body, simple and suitable clothes according to the occasion, presence of senile halo in both eyes.

Conscience: alert.

Humor: euthymic and modulated. 
Thinking: content and production a bit limited, and speed slightly slower than the normal range.

Felt sense: $n o$ signs of hallucinations

Intelligence: on clinical average, not tested.

Abstraction ability: partially impaired.

Cognitive functions (orientation, memory): immediate memory preserved, lapses of recent and remote memories.

Critical judgment: impaired.

Conduct: proper to the occasion.

Language: shows no significant impairment, except for a reduction on hearing, corrected with the use of a hearing aid.

Conclusion: expert mental state examination compatible with initial dementia.

\section{Detailed scores:}

1. Spacial orientation: $4 / 5$

2. Spacial orientation: $4 / 5$

3. Repeat the words: $3 / 3$

4. Calculation: $2 / 5$

5. Memorization: $1 / 3$

6. Language: $2 / 2$

7. Language: $1 / 1$

8. Language: $3 / 3$

9. Language: $1 / 1$

10. Language: $1 / 1$

11. Language: $1 / 1$

Total score: 23/30.

Conclusion: The Examinee showed an impairment in time and space orientation, in the performance of math calculations, and in the recollection of recent and remote memories. As indicated with respect to the test administration in item 4 (calculation), it was requested that the examinee subtracted the number 7 from a total of 100 in five consecutive calculations. There was also a point loss in item 5, indicating problems in the recent memory, through the memorization and recall of the same 3 words in 3 repetitions. He scored under the normal cut applicable to his instruction level. Therefore, his MMSE score was classified as "initial dementia", which is in line with the findings of his expert mental state examination.

\section{DISCUSSION}

Expert evaluations on judicial processes have an important role on judicial interdictions. Despite clinical history and mental state examination constitute mainstream assessments of psychiatric diagnosis, these tests are subjective and depend on the examiner's findings. On this setting, it is necessary to search for more objective and reproducible elements in the analysis offered to the court, enhancing the reliability of the expert findings on judicial decision making process.
In order to perform this, it remains necessary to use already validated diagnostic scales and questionnaires. In this report, we have presented the relevance of MMSE for the screening of dementia in judicial expertise interdiction exams.

In this case, the examinee was diagnosed with "mild dementia," and was subject to interdiction as to the administration of her assets. For such activities, the examinee receives the support of a special curator. Another alternative would be so-called "tomada de decisão apoiada" (supported decision-making), as defined in Brazilian Act 13.146 of $2015^{5}$. This latter measure, initiated by the examinee herself, the minimum of two individuals are judicially appointed, who shall assist the examinee in the administration of his assets and other acts. This main purpose of this measure is to provide the examinee with trustworthy information and analysis, in order for the examinee to make a proper decision in his financial decisions.

\section{CONCLUSIONS}

We have presented a case report regarding a judicial interdiction assessment in a dementiated individual. It was highlighted the relevance on using a screening functioning test as the MMSE in order to provide more objective elements for the court's judging decision making.

\section{INDIVIDUAL CONTRIBUTIONS}

The authors substantially contributed to conception, design, analysis and interpretation of data, substantially contributed to drafting the article, revising it critically for important intellectual content and had given the final approval of the version to be published.

\section{CONFLICTS OF INTEREST}

The authors report no conflict of interest or funding.

\section{REFERENCES}

1. Brasil. Presidência da República. Casa Civil. Lei no 10.406, de 10 de janeiro de 2002. Institui o Código Civil (Internet). Braślia: Casa Civil, 2002. Available from: http://www.planalto. gov.br/ccivil_03/leis/2002/110406.htm.

2. Abdalla Filho E, Chalub M, Telles LEB. Psiquiatria Forense de Taborda. 3a ed. Porto Alegre: Artmed; 2016

3. Barros DM, Teixeira EH, orgs. Manual de perícias psiquiátricas. Porto Alegre: Artmed; 2015.

4. Folstein MF, Folstein SE, McHugh PR. "Mini-Mental State." A practical method for grading the cognitive state of patients for the clinician. J Psychiatr Res. 1975;12(3):189-98.

5. Brasil. Presidência da República. Secretaria-Geral. Subchefia para Assuntos Jurídicos. Lei no 13.146, de 6 de julho de 2015. Available from: http://www.planalto.gov.br/ccivil_03/_ ato2015-2018/2015/lei//13146.htm. 
6. Conselho Federal de Medicina. Resolução CFM no 2.056/2013. Braślia: CFM; 2013. Available from: http://www.portalmedico.org.br/resolucoes/CFM/2013/2056_2013.pdf.

7. Fachel JC, Camey S. Avaliação psicométrica: a qualidade das medidas e o entendimento dos dados. In: Cunha JA, org. Psicodiagnóstico V.5. ed. rev. ampl. Porto Alegre: Artmed; 2000. p. $158-70$.

8. Drevets WC, Price LL, Furey ML. Brain structural and functional abnormalities in mood disorders: implications for neurocircuitry models of depression. Brain Struct Funct. 2008;213(1-2); 93-118.

9. Macqueen GM. Will were be a role for neuroimaging in clinical psychiatry? J Psychiatry Neurosci. 2010;35(5):291-3.

10. Wettstein RM. Quality and quality improvement in forensic mental health evaluations. J Am Acad Psychiatry Law. 2005:33(2):158-75.

11. Suhara T. Neuroimaging in psychiatry: current methods and future direction. Psychiatry Clin Neurosci. 2016;70(7):259-60

12. Moriarty JC. Flickering admissibility: neuroimaging evidence in the U.S. courts. Behave Sci Law. 2008;26(1):29-49.
13. Heilbronner RS, Sweet JJ, Matrix DK, Krull KR, Henry GK, Hart RP. Official position of the American Academy of Clinical Neuropsychology on serial neuropsychological assessments: the utility and challenges of repeat test administrations in clinical and forensic contexts. Clin Neuropsychol. 2010;24(8):1267-78

14. Bishop NA, Lu T, Yankner BA. Neural Mechanisms of ageing and cognitive decline. Nature. 2010;464(7288):529-35.

15. Lang L, Clifford A, Wei L, Zhang D, Leung D, Augustine G, et al. Prevalence and determinants of undetected dementia in the community: a systematic literature review and metaanalysis. BMJ Open. 2017;7(2):e011146

16. Biblioteca Virtual em Saúde. Rede Telessaúde Brasil. Mini Exame do Estado Mental (MEEM). Available from: http://aps.bvs.br/apps/calculadoras/?page=11.

17. Velayudhan L, Ryu SH, Raczek M, Philpot M, Lindesay J, Critchfield M, et al. Review of brief cognitive tests for patients with suspected dementia. Int Psychogeriatr. 2014;26(8):1247-62.

18. Creavin ST, Wisniewski S, Noel-Storr AH, Trevelyan CM, Hampton T, Rayment D, et al. MiniMental State Examination (MMSE) for the detection of dementia in clinically unevaluated people aged 65 and over in community and primary care populations. Cochrane Database Syst Rev. 2016;::CD011145. 